Open Access

\title{
Review of The Pariah Problem: Caste, Religion, and the Social in Modern India by Rupa Viswanath
}

\author{
Arvind Sharma
}

\author{
Correspondence: \\ arvind.sharma@mcgill.ca \\ Religious Studies at McGill \\ University, Montreal, Québec, \\ Canada
}

Keyword: Caste

\section{Book review}

This book is a marvel of meticulous scholarship which fills an important gap in the history of untouchability in Tamil Nadu. It is so well-documented that more than a third of it consists of endnotes and so clearly written that its accomplishment is also best stated in its own words: "Specifically, the book shows how during the thirty years from roughly 1890 to 1920 ways of thinking emerged through the concerted efforts of a 'caste-state nexus' - a de facto alliance between British and Indian officials and native high caste employers of pariah labour - first to elide, and when that was not possible, to downplay and avoid, the problem that the pariah posed. As a consequence of concerted strategies of evasion, the Pariah Problem was only posed and never solved, then as now" (3). The "ways of thinking" involved referred to above are primarily three: (1) that caste, and discrimination based on it, is a religious phenomenon; (2) that social solutions to the problem should be prioritized over political and legal ones such as "the state's enforcement of the fundamental rights to equality and access" (2); and (3) emphasis be placed on "reservation" as a mode of affirmative action, as a substitute for more fundamental structural changes. As the narrative unfolds along these lines, the book becomes an absorbing combination of scholarly erudition, analytical force, and lucid exposition.

However, the book under review seems to assume from the very beginning, and throughout (268 note 48; 388), in keeping with many other accounts found in the literature on the subject, that the untouchables lie outside the Hindu fold. Such an assumption is deeply problematical, especially when found in a book which is otherwise so painstakingly accurate and well-documented. On the key question of whether untouchables fall within or outside the varna, or the class system within Hinduism, (Pandurang Vaman Kane 1962) has this to say:

The varṇas are only four, there is no fifth varṇa (Manu X.4 and Anuśāsanaparva, chap. 48:30), though in modern times untouchables are often spoken of as pañcamas (against smṛti usage) (1962:1633).

The use of avarna would similarly be questionable in smṛti terms. In other words, the untouchables technically fall within (rather than outside) the varna system, although historically they may have come to be placed outside it by some foreign

(c) 2015 Sharma. This is an open access article distributed under the terms of the Creative Commons Attribution License (http:// creativecommons.org/licenses/by/4.0), which permits unrestricted use, distribution, and reproduction in any medium, provided the original work is properly credited. 
observers (see Albïrunī 1910, 1963:101; Dubois 1897, 50). It is therefore important to pursue this point. In classical literature, the untouchables are included within the varna system by dividing the śüdras into nonexcluded (anirvasita) and excluded (niravasita) śúdras (see Patañjali on Pānini 2.4.10). This inclusion of the untouchables within the Hindu fold, however, is not limited to classical Hinduism. The evidence one finds from medieval times on the point is also interesting. While Albiruni seems to place the untouchables outside the varṇa system, the famous commentary on the Yäjñavalkya-smṛti, called the Mitākșarā (c. twelfth century) seems to include them, while commenting on Yäjñavalkya-smriti I.86. Julius Lipner notes:

The Mìtākṣarā (eleventh-twelfth century), the most authoritative and well-known commentary on the Yäjñavalkya-smṛti, recommends, but does not enforce, suttee for all wives, including the caṇ̣āa (one of the lowest castes: 'ā caṇ̣ālam' says the text)... (Lipner 2010: 255).

The historical evidence from this period is even more sensational. During the long period of Muslim rule over India (real or nominal) from c. 1200 onwards until 1858, Hindu rule was established for only four months in 1320, and that too by an untouchable who had converted to Islam but who then reverted to Hinduism (Ahmad 1964: 95-97). His name is given as Khusrau Khān and he "was a low caste parwārī from Gujarat, a community known as mahār, or by the more reviling appellation dhed, generally considered by the Hindus as the very lowest caste except the māng, and regarded as extremely filthy by Caste Hindus" (95-96). This is an unlikely development if we assume that the untouchables lay outside the Hindu fold. Indeed, Aziz Ahmad notes that "Brahmins consecrated the rites of the low-caste Parwāris, a quite unorthodox manifestation of Hindu political solidarity" (96). Untouchables are considered Hindus during the modern period even more explicitly. In fact, according to the order promulgated by the President of India in 1950, known as the Constitution (Scheduled Castes) Order, "no person who professes a religion different from Hinduism shall be deemed to be a member of the Scheduled Caste". Moreover, this provision follows the Government of India (Scheduled Castes) Order of 1936 in doing so (see Smith 1963: 117).

Competing interests

The author declares that he has no competing interest.

\section{References}

Ahmad, Aziz. 1964. Studies in Islamic Culture in the Indian Environment. Oxford: Clarendon.

Albīrunī. 1910. Alberuni's India: An Account of the Religion, Philosophy, Literature, Geography, Chronology, Astronomy, Customs, Laws and Astrology of India about A.D. 1030 (ed. and trans. Edward C. Sachau). Volume 1 of 2. London: Kegan Paul, Trench, Trübner \& Co.

Dubois, Abbé JA. 1897. Hindu Manners, Customs and Ceremonies. Oxford: Clarendon.

Kane, Pandurang Vaman. 1962. History of Dharmaśāstra (Ancient and Medieval Religious and Civil Law in India).

Part 2 of 5 volume in 7 parts. Poona: Bhandarkar Oriental Research Institute.

Lipner, Julius. 2010. Hindus: Their Religious Beliefs and Practices, vol. 1994. London: Routledge.

Smith, Donald Eugene. 1963. India as a Secular State. Princeton, New Jersey: Princeton University Press. 